Derya Göğebakan-Y1ldız, Gizem Engin

Turkish Online Journal of Qualitative Inquiry (TOJQI)

Volume 10, Issue 2, April 2019: 180-214

DOI: $10.17569 /$ tojqi.465686

Research Article

\title{
Migration Education Program for Teacher Candidates ${ }^{1}$
}

\author{
Derya Göğebakan-Yıldız², Gizem Engin ${ }^{3}$
}

\begin{abstract}
This study aims to analyze Migration Education Program (MEP) developed for teacher candidates from the viewpoint of teacher candidates. MEP lasted 8 sessions and consists of topics: Migration phenomenon, Migrant Population in Turkey and World, Globalization and Multiculturalism, Migration and Poverty, Migration and Women, Migration and Children, Migration and Education, and Migration from the Viewpoint of Teacher Candidates. The participants of MEP are 34 volunteer teacher candidates. Case study method which is one of the qualitative research designs is used in this study. The data of the study is collected from teacher candidates' diaries and group interview forms carried out at the end of education program. The results of the study showed that at the end of MEP teacher candidates deepened their knowledge of migration phenomenon; they were able to make more detailed and extensive analysis and inquiries of topics such as migration and globalization, migration and multiculturalism, migration and poverty, migration and women, migration and children, migration and education; they were able to face their own prejudices and improve their viewpoints; and also they found materials used in the program effective. Additionally, the activities most appreciated by teacher candidates were film activity, creative writing, small and large group work activities and case analysis. Finally, it is possible to say that MEP is an educational program which can be used in the training of teacher candidates.
\end{abstract}

Keywords: Migration, migration education program, teacher candidates, diaries.

\footnotetext{
${ }^{1}$ This study was orally presented at the 6th International Congress on Curriculum and Instruction on October 11-13, 2018, Kars, Turkey.

${ }^{2}$ Asst.Prof.Dr., Manisa Celal Bayar University, Demirci Faculty of Education, Department of Educational Sciences, dgogebakan@yahoo.com, https://orcid.org/0000-0002-8831-8878

${ }^{3}$ Asst.Prof.Dr., Ege University, Faculty of Education, Department of Elemantary Education, gizemozen@hotmail.com, https://orcid.org/000-0003-2532-8136
}

Received: 29.09.2018, Accepted: 29.04.2019 


\title{
Öğretmen Adaylarına Yönelik Göç Eğitim Programı
}

\begin{abstract}
$\ddot{\mathbf{O} z}$
Çalışmanın amacı öğretmen adaylarına yönelik olarak geliştirilen Göç Eğitim Programının (GEP) öğretmen adaylarının görüşleri açısından incelenmesidir. 8 oturum süren GEP , Göç Olgusu, Dünya'da ve Türkiye'de Göçmen Nüfus, Küreselleşme ve Çokkültürlülük, Göç ve Yoksulluk, Göç ve Kadın, Göç ve Çocuk, Göç ve Eğitim ve Öğretmen Adayının Perspektifinden Göç temalarından oluşmaktadır. GEP 34 gönüllü öğretmen adayıyla gerçekleştirilmiştir. Araştırmada nitel araştırma desenlerinden durum çalışması kullanılmıştır. Çalışmanın verileri, öğretmen adaylarının günlükleri ve eğitimin sonunda katılımcılarla yapılan grup görüşme formundan elde edilmiştir. Ulaşılan bulgulardan, öğretmen adaylarının bu GEP ile göç olgusu konusunda bilgilerini derinleştirdikleri, göç ve küreselleşme, göç ve çokkültürlülük, göç ve yoksulluk, göç ve kadın, göç ve çocuk, göç ve eğitim konularıyla ilgili daha derin analizler ve sorgulamalar yapabildikleri, kendi önyargılarıly yüzleştikleri, bakış açılarını geliştirdikleri ve kullanılan eğitim materyallerini ve aktiviteleri etkili buldukları anlaşılmaktadır. Ayrıca, öğretmen adaylarının en çok beğendikleri aktivitelerin fillm etkinliği, yaratıcı yazma, küçük ve büyük grup çalışmaları ve durum analizleri olduğu tespit edilmiştir. Son olarak, GEP'in öğretmen adaylarının eğitiminde kullanılabilecek bir eğitim programı olduğu söylenebilir.
\end{abstract}

Anahtar Sözcükler: Göç, göç eğitim programı, öğretmen adayları, günlükler. 


\section{Introduction}

\section{Migration}

The phenomenon of migration is one of the most prominent current issues. The phenomenon of migration is one of the most studied fields for years as it is directly associated with various other fields of study such as healthcare, education and finance. Various definitions were given to define the phenomenon of migration. Basically, migration can be defined as people's voluntary movement of leaving the environment they live in with groups of others or individually to settle some other places temporarily or permanently as a result of war, environmental deterioration, problems in access to educational facilities or due to political or financial problems (Başterzi, 2017, p.380; Doğanay, 1994, p.165; Kaştan, 2015, p.217;). The phenomenon of migration is a powerful fact affecting both people migrating themselves and people who already live in the migrated area. The most common concepts heard about migrating people are immigrant, refugee and defector. When we examine these concepts, it can be seen that there are some differences between them. Third Article of Turkish Settlement Law (2006) defines immigrant as; " People who originate from Turkish lineage and affiliated to Turkish culture and come to Turkey for the purpose of settling down individually or collectively and are approved according to this law". The people who live their country and apply to defect another country are named as defectors while their applications are in process (Başterzi, 2017); and people who leave or forced to leave their country because of certain aspects they possess such as race, religion, language, political views or being part of a certain group and not willing or not allowed to turn back to their homeland as they may be harmed are legally named as refugees (Başterzi, 2017; UNHCR,2018).

All migrating people, whether they are immigrants, refugees or defectors, go through radical changes in their lives. These changes mostly bring about some problems. It is possible to come across various studies carried out about the effects of migration on education, poverty, women, urbanization and multiculturalism (Çağlayan \& Kemik, 2018; Özvarış, 2018; Yalçın, 2015). By the end of 2017, 68,5 million people are known to be forced to migration. 25,4 million of these people are refugees, 40 million are forced to relocate within their countries and 3,1 million people settled in some other countries as defectors (UNHRC, 2018). The numbers given 
above can help us to understand the effects of migration. In this study the topics migration and women, migration and children, migration and education, migration and multiculturalism will be examined under the light of related literature.

\section{Migration and Women}

It is a known fact that the movement of migration deeply affects immigrants' financial situations, socialization patterns and family structures. This situation increases the burden of women's physical, psychological and financial efforts in the family. Women who work for family errands (farm work, house work, etc) before migrating from rural areas to the city usually tend to take paid jobs. However, as women do not get much help from other members of the family, they have to work for their paid jobs as well as non-paid house work which becomes a heavy burden crushing them (Çağlayan \& Kemik,2018). Additionally, women are forced to work menial and low paid jobs (Korkmaz \& Korkut,2012).

It is known that women become a part of this movement because of macro reasons like war, exploitation, violation of human rights as well as micro reasons like domestic problems, financial problems and sexual violence (Barın, 2015; Ünlütürk Ulaş \& Kalfa, 2009). It is difficult to say that women have good standard of living in the places they settle after they immigrate to other countries. Women usually tend to work for home labor (Barın, 2015; Demirdizen, 2013; Ünlütürk Ulaş \& Kalfa, 2009; Yalçın, 2015), child care (Barın, 2015; Demirdizen, 2013; Ünlütürk Ulaş \& Kalfa,2009) and similar jobs and usually send some part of their income to their families (Barın,2015; Ünlütürk Ulaş and Kalfa,2009). Losing social support services after immigration, and lacking adequate knowledge of language, culture and legal status of their new country affect their living conditions negatively (Saraydin, 2007). It is also known that immigrant women are subject to financial, physical, emotional and sexual abuse (Yalçın, 2015). Immigrant women experience various problems like difficulty in communication, reaching information, making use of health services and besides they are subjected to more discrimination just because of their gender (Özvarış, 2018). 


\section{Migration and Children}

As well as women, children are the most effected ones from migration (Aydın, Şahin \& Akay, 2017; Gözübüyük et al., 2015; Özvarış, 2018). Migration causes children to be exposed to extensive problems such as sexual abuse or rape, suffering from illnesses because of deterioration of medical conditions, being unable to reach health services they need, and being bought and sold as if they are property (Özvarış, 2018).

As children are more vulnerable to external factors they suffer physically, socially and emotionally more seriously than others from the events during or post migration (Aydın, Şahin \& Akay, 2017; Baş et al., 2017; IOM, 2012; Özvarış, 2018). The children that leave their environment may experience difficulties in fitting into a new environment. Immigrant children cannot reach adequate nourishment and sheltering due to financial insufficiency. UNICEF (2016), reported acute malnutrition (medium level) in 45 children among 2200 immigrant children after a health scan they carried out and intervened the situation (Aydın, Şahin \& Akay, 2017). These children developmentally fall behind as they are undernourished or catch illnesses because of hygiene problems. These illnesses turn into epidemics in the migrated areas because of low rate of vaccination (Baş et al., 2017; Şener \& Orakç1, 2014). Additionally, children experiencing compliance problems and feeling constantly threatened by the new environment develop negative feelings towards themselves and their environment thus increasing probability of criminal behavior (Aydın, Şahin \& Akay, 2017; Kaştan, 2015).

Immigrant children's labor is also exploited. These children are used for menial jobs (Apak, 2014; Deniz, Hülür \& Ekinci, 2016; Kağnıc1, 2017). From very young ages they are forced to work for textile industry, construction, agriculture, animal husbandry (IOM, 2012), hawking (tissue papers etc.), collecting paper from dumpsters (Kaştan, 2015; Baş et al.,2017). Very young girls, who can be called as children, can be forced to marry with religious marriage (undocumented marriage) instead of attending their schools. It is known that so called childbrides may be as young as 11-12 years old (Türkay, 2016; Baş et al;2017). 


\section{Immigration and Education}

Migrating parents cannot take care of their children's educational needs and provide them with opportunities to study their lessons as they have to deal with many other problems and sometimes they even have to force their children to work to contribute family budget (Baş et al.,2017; Kaştan, 2015;) or these parents may even force their children to get married (Türkay, 2016). Therefore, the number of immigrant children who cannot attend schools is increasing and even they can attend schools their achievement levels are low. For example, according to UNICEF 2016 July report, the number of Syrian immigrant children is 1.6 million and more than 500.000 of these children are out of school.

The children who have to change their schools after immigration and they can experience difficulties in fitting into their new schools. This situation causes unwillingness towards school (Aydın, Şahin \& Akay, 2017; Kaştan, 2015). Another important reason for low achievement levels is indubitably language problem immigrant children experience (Apak, 2014; Deniz, Hülür \& Ekinci, 2016; Kağnıc1, 2017).

As a result of rapidly increasing migration children from various national backgrounds can be in the same class. For example, 1 of every 2 children receiving education in Rotterdam and Amsterdam are immigrants (Papademetriou \& Weidenfeld, 2007 cited in Schröttner, 2012). Other problems with immigrant children's education are as follows: they have to receive education with younger age students because of their language problem, they usually have to choose vocational programs, they may be subject to discrimination, they may have difficulty in gaining some cultural skills taught at schools, and having limited career options (Schröttner, 2012:1).

International organizations and governments work together to overcome above mentioned schooling and school achievement problems. For example, UNCHR (2018) stated that they focus on these problems together with Turkish Ministry of Education and universities. They also reported that $62 \%$ of all Syrian children in Turkey are involved in formal education, 20000 Syrian youngsters are enrolled in universities, 1152 students are supported by UNCHR with full scholarship, and 4292 students benefit from prepatory programs for higher education which are supported by UNCHR. 


\section{Migration and Multiculturalism}

Today, it is widely known that there is a worldwide movement of people from different languages, religions, cultures, races and ethnicity as an outcome of globalization. With this aspect, globalization replaces cultural diversity and multiplism with the concept of local culture (Schröttner, 2012). This situation requires reviewing perception of national identity and new types of citizenship (e.g. world citizenship) in addition to national citizenship (Giddens, 2008). The concept of multiculturalism rejects assimilation because it views assimilation as dominant culture's taking minority's place. Instead, it proposes a structure in which each ethnic and racial element maintanins its distinctiveness just as a "saladbowl". (Kukhatas 2008:51 cited in Barın, 2016) The cultural diversity emphasis of multiculturalism emphasizes coexistence of nations with different languages and cultural features without losing their distinct characteristics (Damgacı \& Aydın, 2013). These cultural characteristics are summarized by Banks (2001:76, cited in Damgacı \& Aydın, 2013:329):

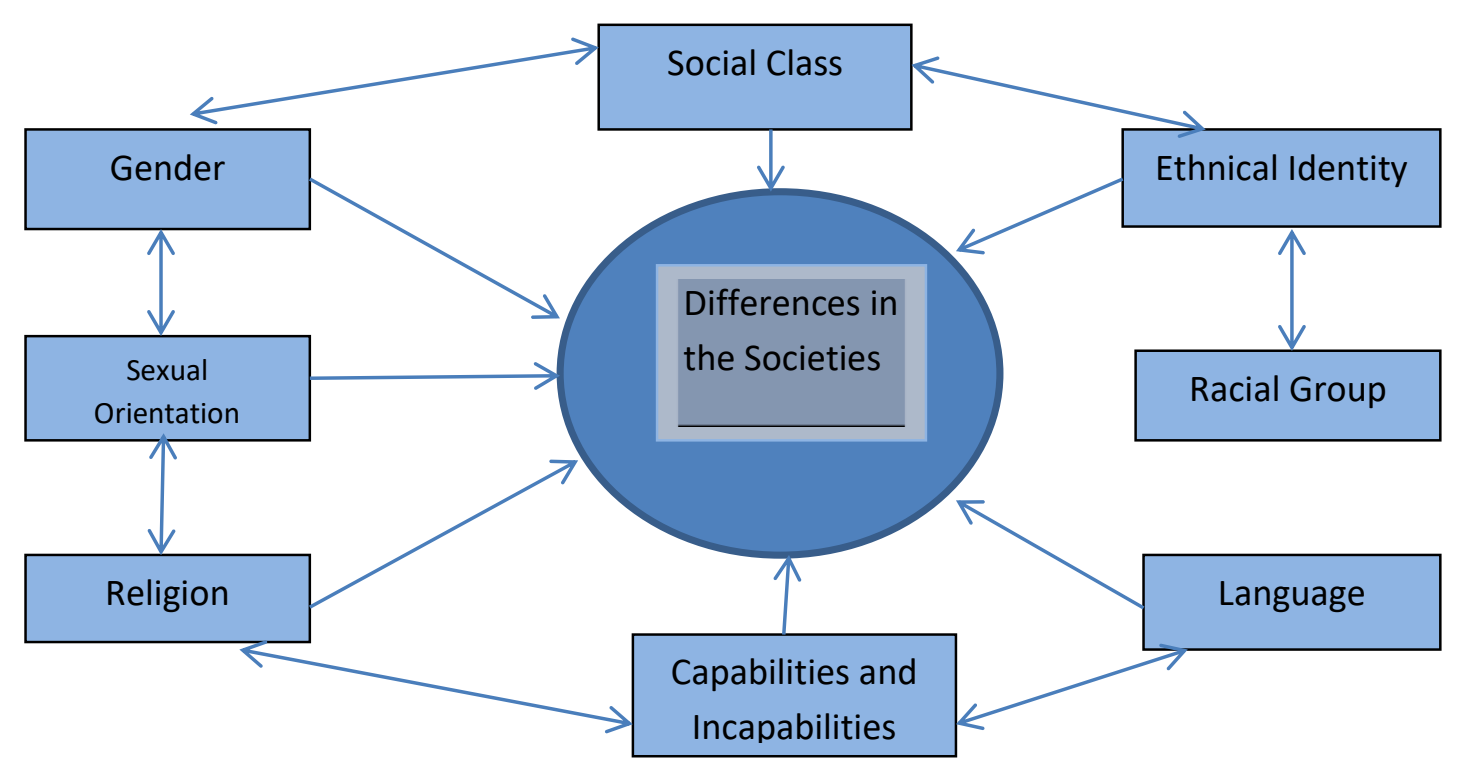

Figure 1. Cultural differences in societies

One of the most prominent factors increasing cultural diversity shown in table 1 is undoubtedly immigration (Başbay, 2014). It is necessary to make possible that this diversity coexist and 
serve the whole community. There are examples of concerns in the literature that emphasis on diversity in multiculturalism weakens the concept of nation-state (Altınbaş, 2006). On the other hand, there are criticism about emphasis on unity leading way to cultural oppression (Yalçın, 2002). Therefore, diversity and unity must be approached very carefully in a multicultural country (Başbay, 2014; Damgacı \& Aydın, 2013).

Lastly, the phenomenon of migration and its effects have surrounded the world and Turkey. Turkey has taken its place among the countries hosting the highest number of immigrants after experiencing major waves of mass migration. It is also known that 1.6 million of 3.6 million Syrian immigrants are at school age. It is obvious that the phenomenon of migration and its effects are going to have a major impact on Turkish educational system for many years. In this context, it is vital for teachers and teacher candidates to develop their knowledge and skills about the phenomenon of migration. For this reason, the aim of this study is to examine the MEP developed for teacher candidates from the viewpoints of teacher candidates. In relation to this aim, two research questions are posed:

1) How do teacher candidates evaluate MEP according to the answers they gave in the diaries?

2) How do teacher candidates evaluate MEP according to the answers they gave to the evaluation questions?

\section{Method}

Single-case embedded research design which is one of the case study research designs is used in this study. Case study takes place in the real environment of an up-to-date case and it is a comprehensive-qualitative research design preferred in cases in which the case and lived environment are nested and various data sources are available (Yıldırım \& Şimşek, 2008). Teacher candidates, diaries and group interviews are used as data sources. The existing situation of Migration Education Program is described and possible contributions to the program are expected. 


\section{The Case}

Migration Education Program is developed by researchers for teachers and teacher candidates. Aims, content, educational conditions and evaluation process of the developed are explained in the following paragraphs.

\section{The Need for Education}

The websites of various universities were examined but no course directly related to migration could be detected. However, some related courses such as: "Teaching Turkish to Foreigners" which is a mandatory course for Turkish teachers, "Children at Risk" which is an elective course in pre-school teaching departments of some universities, and "The History of Turkish Immigration" course in social studies departments were identified.

\section{Specifying the Aims of Migration Education}

The phenomenon of migration (Başterzi, 2017; Brettell, 2000 cited in.Pala,2013 ), migration and women (Barın, 2015; Çağlayan \& Kemik, 2018; Korkmaz \& Korkut,2012; Yalçın,2015), migration and children (Aydın, Şahin \& Akay, 2017; Gözübüyük et al., 2015; Özvarış, 2018), migration and education (Apak, 2014; Aydın, Şahin \& Akay, 2017; Deniz, Hülür \& Ekinci, 2016; Kağnıc1, 2017; Kaştan, 2015), multiculturalism and globalisation (Giddens, 2008; Schröttner, 2012) were related literature reviewed for the study.

After the literature review the aims of Migration Education Program were specified and they are as follows:

1. Defines the phenomenon of migration.

2. Defines types of migration.

3. Explains causes and results of migration.

4. Explains concepts of immigrant, refugee and defector.

5. Examines characteristics of immigrant population in the world and Turkey.

6. Relates the phenomenon of migration with globalization and multiculturalism.

7. Analyzes the relation between phenomenon of migration and poverty.

8. Evaluates the effects of the migration on women. 
9. Examines the characteristics of child immigrant population in the world and Turkey.

10. Evaluates the effects of the migration on children.

11. Defines the characteristics of educational systems sensitive to migration.

12. Expresses the characteristics of a teacher working in an immigrant populated school.

13. Uses conflict resolution skills in a migration sensitive school.

14. Reconstructs the effects of migration from different viewpoints.

\section{Specifying the Content and Activities}

The course content consists of articles, books, films and reports to ensure Migration Education Program reaches its goals. Themes and contents of Migration Education Program is given in Table 1.

Table 1

Themes and Contents of Migration Education Program

\begin{tabular}{|c|c|}
\hline Theme Number & Content/Activity \\
\hline $\begin{array}{l}\text { 1.Theme: The } \\
\text { Phenomenon of Migration } \\
\text { 28.03.2018 }\end{array}$ & $\begin{array}{l}\text { *Defining the concepts of migration, types of migration, causes and effects of } \\
\text { migration, immigrant, refugee and defector. } \\
\text { Article Activity: "Migration and Human" (Ekici and Tuncel, 2015) }\end{array}$ \\
\hline $\begin{array}{l}\text { 2.Theme: Immigrant } \\
\text { population in the world } \\
\text { and Turkey } \\
04.04 .2018\end{array}$ & $\begin{array}{l}\text { * Characteristics of immigrant population in the world and Turkey } \\
\text { Informative Text: Refugees in the world and Turkey (BMMYK, 2015). }\end{array}$ \\
\hline $\begin{array}{l}\text { 3.Theme: Migration, } \\
\text { globalization and } \\
\text { multiculturalism } \\
\text { 11.04.2018 }\end{array}$ & $\begin{array}{l}\text { *The relation between migration and globalization } \\
\text { Article Activity: } \\
\text { "The Changing Perception of Immigrants in the Relation of Globalization } \\
\text { and International Migration" (Köş ve Özbek, 2017). } \\
\text { "World, The Place of Exiles: Migration, Multiculturalism and Othering" } \\
\text { (Canbay Tatar, 2013) }\end{array}$ \\
\hline $\begin{array}{l}\text { 4.Theme: Migration and } \\
\text { Poverty } \\
\text { 18.04.2018 }\end{array}$ & $\begin{array}{l}\text { *The relation between migration and poverty. } \\
\text { Book Activity: The Land (Torres, 2017) }\end{array}$ \\
\hline $\begin{array}{l}\text { 5.Theme: Migration and } \\
\text { Women } \\
\text { 25.04.2018 }\end{array}$ & $\begin{array}{l}\text { *The effects of migration on women } \\
\text { Film Activity: Dancer in the Dark (VonTrier, 2000) }\end{array}$ \\
\hline $\begin{array}{l}\text { 6.Theme: Migration and } \\
\text { Children } \\
\text { 02.05.2018 }\end{array}$ & $\begin{array}{l}\text { *Characteristics of immigrant child population in the world and Turkey } \\
\text { *The effects of migration on children } \\
\text { Survey of Reports: } \\
\text { Turkish Immigration Report (GIGM, 2016) } \\
\text { Children Uprooted: The growing crisis for refugee and migrant } \\
\text { children (UNICEF, 2016) }\end{array}$ \\
\hline $\begin{array}{l}\text { 7.Theme: Migration and } \\
\text { Education } \\
\text { 09.05.2018 }\end{array}$ & $\begin{array}{l}* \text { The characteristics of an educational system sensitive to migration } \\
* \text { The characteristics of a teacher working in an immigrant populated school } \\
\text { Article Activity: }\end{array}$ \\
\hline
\end{tabular}




\begin{tabular}{ll}
\hline Theme Number & Content/Activity \\
\hline & "An Evaluation of the Relationship of Immigration and Education: Education \\
& Needs of the Syrian Refugee Children and Challenges of Exposed Delays in \\
& Schooling Process"(Gencer, 2017) \\
\hline 8.Theme: Conflict & *Using conflict resolution skills in school and classroom. \\
Resolution Skills/ & Activity: \\
Immigration from the & Creating conflict scenarios related to immigration. \\
Viewpoint of Teacher & Application of conflict resolution skills based on the created scenarios. \\
Candidate & * Reconstruction of the phenomenon of migration by teacher candidates. \\
16.05 .2018 & Activity: Application of six thinking hats technique by teacher candidates. \\
\hline
\end{tabular}

Detailed information about articles, reports, books and movies included in the content of Migration Education Program is as follows:

\section{Articles}

The article "Migration and Human" (Ekici \& Tuncel, 2015) is chosen to discuss the topics like definition of migration, basic concepts of migration, types and causes of migration. The articles "The Changing Perception of Immigrants in the Relation of Globalization and International Migration” (Köşk \& Özbek, 2017), “World, The Place of Exiles: Migration, Multiculturalism and Othering" (Canbay Tatar, 2013) are chosen to examine the relation between phenomenon of migration, globalization and multiculturalism. The article "An Evaluation of the Relationship of Immigration and Education: Education Needs of the Syrian Refugee Children and Challenges of Exposed Delays in Schooling Process"'(Gencer, 2017) is chosen to reveal the relation between migration and education.

\section{National and International Reports}

The reports Turkish Immigration Report (GIGM, 2016) and Children Uprooted: The growing crisis for refugee and migrant children (UNICEF, 2016) were examined to discuss the situation of children effected from migration in the world and Turkey.

\section{Book and Film}

"The Land" written by Antonio Torres (2017) and "Dancer in the Dark" directed by Lars Von Trier (2000) starring Björk are chosen to discuss the topics migration and women, migration 
and men, migration and poverty. Teacher candidates carried out book reading and film watching duties out of the classroom and enough time was given them to carry out these tasks.

\section{Design of Educational Experiences}

It is emphasized that teachers working in multicultural environments crated by phenomenon of migration have constructivist views of education. In these environments, students must be provided with opportunities to construct, inquire and interpret knowledge. It is quite likely that teacher candidates, who are not given the opportunity to interpret, solve problems, explain the results, defend their arguments, and discuss their arguments, will not be able to give these opportunities to their students (Başbay \& Bektaş, 2009). For this reason, the implementation process of MEP includes large and small group discussions, sample case studies, creative writing, question-answer, brainstorming, generating ideas, talking circles, six hat thinking technique, conflict resolution and etc. Also, the film, the book, articles and other documents used in MEP were shared with teacher candidates before sessions to ensure that they have enough time to watch, read and get ready for sessions.

\section{Evaluation of Procedures}

MEP was carried out with volunteer teacher candidates for 8 sessions. The diaries written by teacher candidates were collected after each session. Additionally, focus group interviews were done to collect data about the efficiency of the program. The results of the interviews are presented in the results section.

\section{Participants}

The program was carried out with a total of 34 volunteer teacher candidates. 19 of the participant are females and 15 participants are male students and they were studying at departments of social studies, science, classroom teaching and psychological counseling and guidance. All of the participants attended all sessions during the eight week procedure. 


\section{Data Collection Tools}

Diaries written by teacher candidates were collected from all participants after each session. Additionally, group interviews were done with teacher candidates to evaluate the effectiveness of the MEP at the end of the procedure.

\section{Teacher Candidates' Diaries}

Teacher candidates were required to keep diaries about each session in which they commented on and evaluated MEP sessions. Diaries they kept were collected right after each session.

\section{Group Interviews}

Group interviews with teacher candidates were done at the end of procedure to evaluate the effectiveness of educational activities. Three questions posed to teacher candidates at group interviews are as follows:

1) What do you think are the effects of MEP on teacher candidates participating in the program?

2) What is the activity you most favored in MEP?

3) What are your suggestions to improve MEP?

\section{Data Collection and Analysis}

The data of the research was collected continuously through the procedure. Teacher candidates expressed their views about each session in their diaries. These diaries were collected by the researcher. Additionally, participants were interviewed in three groups at the end of the program. Each interview took approximately 40-50 minutes. The diaries collected during MEP and data collected from interviews were analyzed using qualitative data analysis techniques. The data collected in the research was analyzed in accordance with thematic frame of MEP. Descriptive analysis was used in direct quotations (Yıldırım and Şimşek 2008). Teacher candidates were encoded as TC1, TC2....TC34 in direct quotations. 


\section{Validity and Reliability}

Some special strategies were followed to ensure validity and reliability of the study. Long-term interaction method was used to ensure internal validity. Mutual agreement was established in group rules, break times of sessions, confidentiality and mutual trust. Secondly, participator approval was confirmed. To this aim, the interviews were written down and they were read by four randomly chosen teacher candidates. Thirdly, direct quotations were given without adding any comments to them. Fourthly, the data were collected in two different ways which are diaries and interviews and quotations are chosen from different participators. Fifthly, the structure of Migration Education program, research design and detailed information about collection and analysis of the data is included. Lastly, the researcher in qualitative studies is the one who spends time in his/her related field, experiences the events happening in the field, knows about the field and communicates with people participating in the study (Y1ldirım \& Şimşek, 2008). In qualitative research the researcher is also considered as a data collection tool (Mertens, 1998). For this reason, it is important to explain the role of researcher in the study. Researchers are experts academicians of educational programs and their fields of teaching. Both researchers in the study have comprehensive knowledge of curriculum development, evaluation, teacher training, and teaching-learning procedures. Additionally, both researchers carry out teacher training projects in coordination with governmental and non-governmental organizations.

\section{Findings}

The findings of the study are presented under two categories which are teacher candidates' diaries and interviews.

\section{Analysis of Teacher Candidates' Diaries}

The diaries written by teacher candidates after each session are analyzed under four main headings which are: Article and report examinations, book analysis, film analysis, conflict resolution and six hats thinking technique activities. The findings are as follows: 


\section{Findings related to article and report examination activities}

Teacher candidates examined the articles and reports presented to them before sessions and they participated in activities in sessions. Some quotations written by participants after sessions are presented below.

\section{The phenomenon of migration}

Some quotations taken from sessions in which teacher candidates discussed about the phenomenon of migration, types of migration, immigrant, refugee, defector are given below.

A teacher candidate explaining the concept of refugee stated “.... refugees are people who are out of their countries and cannot turn back or not willing to turn back to their countries as they are scared of persecution because of their religion, language, religious sect, or political views" (TC-3, 28.03.2018). Another teacher candidate expressed it as "Defectors are people who appeal as international refugees but their formal status haven't yet been certified by authorities. Defectors cannot be forced to turn back to their home countries" (TC-17, 28.03.2018)

Another teacher candidate defined inland migration in Turkey with these words " Internal migration in our country starting from 60s and 70s with sociological and financial reasons caused many problems especially in education, agriculture, husbandry, unplanned urbanization and economy..." (TC-13, 28.03.2018) and another one explaining international migration expressed

"With the beginning of 19th century people from underdeveloped countries started to immigrate to developed countries for better living standards and starting from 1960s the world witnessed brain drain which is immigration of so called whitecollar workers who made more qualified parts of population. However, with the beginning of 21st century re-sharing plans of the worlds resources caused civil wars in middle eastern countries forced people to flee from their countries" TC-2 (28.03.2018).

Given examples show that teacher candidates can define frequently confused concepts like migration, immigrant, refugee and defector suitable to their definitions in the literature and they 
are aware of legal rights of these people. Additionally, they can analyze the current situation of internal and international migration in Turkey and in the world.

\section{Immigrant population in the world, globalization and multiculturalism}

The quotations made from teacher candidates diaries after the sessions about the characteristics of immigrant population in the world and analysis of the phenomenon of migration in the context of globalization and multiculturalism are as follows:

One of the teacher candidates examining reports of immigrant population addressed characteristics of immigrant population in the world and Turkey by stating:

"According to UN, the number of international immigrants have risen to 258 million. $\% 48$ of them are women and it is known that immigrant women have big problems in this harsh living conditions. The numbers also indicate that the number of immigrants or refugees in Turkey is 3 million 570 thousand in 2018. These huge numbers trigger many sociological, financial and educational problems both in Turkey and in the world." (TC-9, 04.04.2018)

After the session about relation between globalization, multiculturalism and migration TC-30 (11.04.2018) stated that "Globalization did not only bring along many major developments in technology, economy and information technologies but also caused problems in global justice, terror, unequal distribution of resources and migration”.

Another teacher candidate summarized the conditions of immigrants by saying: "Migration interrupts socialization of immigrants by invalidating their usual social norms and many other things they learnt" (TC-17, 11.04.2018). Another teacher candidate indicating multicultural living culture as an important factor to minimize traumatic effects of migration by saying "Any society that doesn't have a multicultural structure would have a dismissive attitude to immigrants. The solution is reconciling the society with multiculturalism” TC-27 (11.04.2018) A close examination of teacher candidates' diaries in this section shows that teacher candidates can analyze cause and effect relations between the phenomenon of migration, globalization and multiculturalism in technological and cultural context. 


\section{Immigrant children}

After the session about immigrant children's situation in Turkey and in the world, teacher candidates summarized terrible condition of immigrant children in their diaries with following words: "Children under the age of 18 make 51\% of all refugees. Human Rights Watch Organization reported that more than half of immigrant children are deprived of education. Especially orphan children are the ones most suffering from exploitation of human trafficking." TC-24 (02.05.2018). Another participant drawing attention to tragedies of refugee children expressed that " So many children die during the process of immigration like Aylan the baby whose death made tremendous impact on the world" TC-24 (02.05.2018).

TC-12 drawing attention to the difficulties of refugee children in Turkey expressed that "There are around 3.6 million Syrian individuals in Turkey and around 1.5 million of them are children. 350 thousand of these children are out of school system. Most of these children are open to abuse as they don't have some of their legal documents" (TC-12, 02.05.2018). Another teacher candidate indicates harsh living conditions of immigrant children by saying

"Whatever the reason for their migration might be, these children are socially, culturally and physically negatively affected from migration. The families have to cope with various problems such as health, security, occupation and sheltering and they inevitably reflect these problems to their children which makes them disadvantaged against the hosting people. These harsh conditions may lead to traumas and compliancy problems. " (TC-28, 02.05.2018)

Teacher candidates expressed that children are one of the most disadvantaged groups in migration. Additionally, they expressed that harsh living conditions after migration threaten many civil right of children like health, education and etc.

\section{Migration sensitive educational system}

Some quotations from the session in which a migration sensitive educational system was discussed and brainstorming activities were carried out are given below. 


\section{Characteristics of migration sensitive educational system}

Characteristics of Migration Sensitive Educational System are reflected from the viewpoints of teacher candidates are as follows:

"Approaching all students with same manner can cause limiting students' skills and creativity. For this reason, the most important characteristic of migration sensitive educational system is creating an atmosphere in which diversity is respected." (TC$6,09.05 .2018)$

"Principally, basic problems of the children who experienced immigration must be dealt with. The most important ones of these problems are language, compliance, peer conflicts and indifference of parents." (TC-21, 09.05.2018)

"In migration sensitive educational systems there must be adaptation programs and crisis response programs to efficiently avoid traumatic events." (TC-34, 09.05.2018)

"Aside from academic skills, there must be plenty of sports and art activities which can help improvement of self-expression skills of immigrant children." (TC-15, 09.05.2018)

"There have to be a system that can resolve the problem of inequality between immigrant children and other students." (TC-1, 09.05.2018)

"It is vital to include intercultural learning activities in the curriculum. A migration sensitive educational system must focus on immigrant children's access to education, their participation and learning outcomes. Also, there have to be counseling psychologists who can help these children." (TC-32, 09.05.2018)

"Because of various reasons like culture, gender and financial problems many immigrant children do not have access to education. The most disadvantaged groups in this case are girls and child workers whose labors are exploited. Governmental and non-governmental organizations must work very hard to put these children into schooling system." (TC-4, 09.05.2018)

Analysis of diaries show that teacher candidates are aware of immigrant children's educational problems and they can have a deep understanding of migration sensitive educational systems.

\section{Characteristics of teachers in migration sensitive educational system}

Quotations from diaries written after the session about characteristics of teachers in migration sensitive educational system are given below. 
"They must be sensitive to cultural differences and they must be world citizens who are open to a multicultural social structure. They must be able to emotionally connect with their students." (TC-26, 09.05.2018)

"Teachers must be trained for peace education and human rights and also have skills for conflict resolution and mediation."(TC-26, 09.05.2018)

"They must use educational games, creative drama, cooperative learning, problem solving techniques and etc. in the classrooms to increase communication between immigrant children and other children and help them actively participate in the classroom."(TC-22, 09.05.2018)

"They must be critically thinking, peaceful, empathetic, open minded, nondiscriminative, and they must have high moral values." (TC-7, 09.05.2018)

We can understand from above quotations that teacher candidates can describe characteristics of teachers in migration sensitive educational system from a wide range of qualities which are professional competencies and personal qualities.

\section{Findings related to book analysis (migration and poverty): The Land}

The Land (2017) written by Antonio Torres was chosen to discuss the relation between migration and poverty. Quotations from teacher candidates diaries written after the session about migration and poverty are given in the following paragraphs.

One of the teacher candidates taking his ideas from Nelo's Story in The Land relates migration and poverty with these words: "Poverty is one of the most important causes of migration. When poverty increase, people's desire to leave the places they live for better standards of living." (TC-30, 18.04.2018)

Another teacher candidate expresses how migration is viewed as a way of getting rid of poverty with these words: "Poverty is one of the reasons why Nelo leaves his hometown. Because people want more than breathing or a life that offers them more than filling their stomach and they are right to do so. Nelo prefers to migrate to the city to as he thinks of improving his life standards instead of spending all of his life in poverty." (TC-2, 18.04.2018) 
Another teacher candidate drawing attention to the reality that migration cannot be the only remedy for poverty by saying "Individuals dream of getting rid of all negative consequences of poverty in the place they migrate. Unfortunately, carrying the burden of all hopes of a family, compliance problems, unemployment, insufficient social support and discrimination they face make them wake from these dreams. "'(TC-5, 18.04.2018)

Analysis of all diaries show that teacher candidates based on their experience from Nelo character in The Land and other major waves of migration in the world express that financial problems are the most important motives triggering immigration. However, they emphasize in their diaries that migrating to overcome poverty lays some very heavy burdens on these people.

\section{Findings related to film analysis (migration and women): Dancer in the Dark}

The film Dancer in the Dark (Von Trier, 2000) was chosen to discuss the effects of migration on women. Quotations from teacher candidates diaries they wrote after the film analysis are given below.

A teacher candidate viewing society from the point of gender inequality and migration states that "Aside from being a difficult or even traumatic event, the phenomenon of migration becomes much more painful for women because of disadvantages brought to them by gender inequality ... " (TC-32, 25.04.2018) and another teacher candidate expresses that "As in most other situations, women face more difficulty than men in migration. There are more job opportunities for men and they are paid more than women. People don't even look normally to single women or to single mothers. Selma challenges this viewpoint."'(TC-8, 25.04.2018)

Another teacher candidate discussing migration and women topic in relation with The Land and Dancer in the Dark states that "Nelo in The Land hates the county life and they live in and walks away from this place by himself without anyone's help. However, Nelo's sisters cannot leave the place though they hate it. They all run away with some men. In fact, as a women, I believe that we can overcome these issues just like Selma. "(TC-20, 25.04.2018) 
TC-13 viewing the relation between women and migration from the perspective of poverty expresses that "Discrimination and prejudices towards women become more cruel towards a single immigrant mother...” (25.04.2018)

Another teacher candidate refers to immigrant women's conditions by saying "Vulnerability of immigrant women make them open to all kinds of sexual, financial and emotional exploitation and abuse. The story of Selma is the story of numerous immigrant women. Protecting immigrant from these kind of abuse must be responsibility of all institutions and organizations.." (TC-9, 25.04.2018)

Lastly, teacher candidates were asked to draw emotions-time graphic line of Selma who is the main character in Dancer in the Dark movie and analyze an immigrant woman's emotions. Analysis of the graphics showed that the most dominant feelings in the movie were sorrow, fear, anger, confusion and disappointment. Music, rhythm and dreams are more prominent in all happiness scenes of Selma. Music is the only shelter she can find against the harsh conditions of life and she even goes to death by singing.

Analysis of the diaries written after film sessions showed that teacher candidates can make detailed analysis of financial, social, emotional and sexual traumatic effects of migration on women.

\section{Findings related to conflict resolution and Six Hats Thinking Technique}

In this activity, teacher candidates prepared various conflict scenarios which may emerge in schools affected from the phenomenon of migration. Later, these scenarios were acted using creative drama and conflict were tried to be resolved following conflict resolution stages. Quotations from teacher candidates diaries are given below.

A teacher candidate explains scenario creation process by saying: "I and my group friends primarily tried to describe distinguishing features of the atmosphere of classrooms where immigrant children receive education and secondly we crated scenarios that can represent this atmosphere."(TC-12, 16.05.2018) Another teacher candidate emphasizes importance of conflict resolution skills in the resolution of conflicts by saying: "Diversity inevitably brings 
out conflicts. The important thing is resolving these conflicts in a positive manner. I will teach these skills to my students too.."(TC-18, 16.05.2018).

The last activity in the last session of MEP is six hats thinking $t$ technique activity. The aim of this activity was reconstruction of immigration by teacher candidates. The analysis of teacher candidates' diaries after this session showed that impartial and objective information and data such as compliance problems, causes and effects of migration, characteristics of immigrant population in the world and Turkey were given under the title white hat.

The most recurrent positive feelings under the title red hat were having hope, happiness, delight and the most recurrent negative feelings were sadness, disappointment, unhappiness, loneliness, regret, yearning, social exclusion, poverty, stress, trauma, fear of hunger, fear of being unable to turn back to homeland.

Teacher candidates summarized positive sides of migration under the title yellow hat which included: Immigrants; can benefit from better educational, health, financial and social facilities and services; they may find opportunity to reach their desired lifestyle; open a blank page in their lives; culture and art opportunities and libraries can help them increase their cultural awareness and knowledge; they can increase their living standards; they can help growth of culture and economy of the place they migrate with cultural interaction and workforce.

Opportunities that can be created by phenomenon of migration were summarized under the title green hat with following words: Talented people from various fields like art, sports, literature can come together to create products; entrepreneurs can benefit from immigrants ideas to develop various projects and products suitable to multicultural life.

Teacher candidates summarized their ideas about phenomenon of migration under the title blue hat with these words: Migration has positive and negative social and financial effects on both immigrants and people living in the migrated country. It is essential to minimize negative effects of migration. The most important responsibility of all countries and civil society organizations in the world is securing all immigrants' and especially women and children's' safety, housing, health and educational needs. 
Teacher candidates' diaries written after six hats thinking activity show that teacher candidates can carefully analyze the phenomenon of migration from its various aspects.

\section{Finding related to group interviews}

Three questions were posed in the focus group interviews in order to reveal how teacher candidates evaluated migration education program. The questions are as follows:

1) What do you think are the effects of MEP to teacher candidates participated in program?

2) What is the activity you most favored in MEP?

3) What are your suggestions for improvement of MEP?

1) To the question "What do you think are the effects of MEP to teacher candidates participated in program?" all teacher candidates answered that they found MEP effective. Some of the answers given in the group interviews are given below.

"Our country is facing one of the biggest migration waves of its history. With this education program and similar other programs teachers can make their students social integration easier.." (Ö21)

"Teachers who have received such an education can more easily overcome cultural conflicts which will probably emerge in their classrooms. "(Ö16)

"As a matter of fact, we also immigrate to other places to carry out our duties as teachers. I believe that this education will help us to integrate more easily in the places we will work in future. "(Ö8)

"I believe that such an education will empower teachers' classroom management skills in classes where there is a lot of individual differences." (Ö29)

"This program gave us the opportunity to view various aspects of migration in the world such as women, children and poverty. I believe that it made me aware of all of these" (Ö2)

"I believe that this kind of an education will strengthen teacher candidates' empathy." (Ö13)

"MEP made me feel curious about other cultures and broadened my viewpoint." (Ö22) 
Teacher candidates expressed that with the help of MEP: They learned basic concepts and legal structure about migration; they increased their professional knowledge and skills which they can use in a multicultural context; they broadened their viewpoints about migration and its effects.

2) The second question posed in group interviews was "What is the activity you most favored in MEP?" A general evaluation of the answers showed that teacher candidates found content and activities of MEP effective. The most effective activity was found to be film analysis (f:30). In addition to film analysis, creation and acting of conflict resolution scenarios and six hats thinking activity were the most appreciated activities by teacher candidates. Also, they found small and big group discussion of articles and reports beneficial.

3) Some of the answers teacher candidates given to the question "What are your suggestions for improvement of MEP?" are given below.

"Some experts working in refugee camps can be invited to the sessions." (Ö33)

"Creative drama activities about life scenarios of immigrants can be included more." (Ö4)

“Documentaries about migration can be used. " (Ö6)

"More case studies about traumas that immigrant children lived can be included." (Ö25)

"Some visits to temporary education centers can be included to the content of MEP.” (Ö20)

"More films about immigration can be watched and analyzed." (Ö17)

"MEP actually teaches us to effectively handle differences, accept multicultural education and carry these things to the classroom processes. I believe that I have started doing these with the help of MEP." (Ö9)

Teacher candidates suggested watching more films and documentaries, inviting experts, arranging field trips, and including more creative drama activities in order to improve MEP. 


\section{Discussion and Conclusion}

The aim of this study is to analyze MEP from the viewpoints of teacher candidates. The data of the study was collected from diaries which teacher candidates wrote after each session and group interviews which took place after the completion of MEP.

The first finding of the study is related to first sessions in which characteristics of immigrant population in the world were discussed. Analysis of teacher candidates showed that teacher candidates defined the phenomenon of migration, types of migration, causes and effects of migration, immigrant, refugee and defector consistent with related literature (Başterzi, 2017; Doğanay, 1994; Kaştan, 2015). In class discussions demonstrated that the topics were deeply analyzed. Teacher candidates also expressed that discussing current situation of immigrants in the world and Turkey in the light of reports was very beneficial to them and deepened their knowledge of the subject.

Another finding of the study is related to the session in which the phenomenon of migration was discussed in context of globalization and multiculturalism. The findings showed that teacher candidates mentioned both positive and negative aspects of globalization. Some of the teacher candidates viewed globalization as an important opportunity whereas others viewed it as a negative factor affecting citizens of both developed and developing countries. These teacher candidates stated that globalization is a power that turns the wheels of capitalism and causes wars which tears people off their homelands and forces them to migrate to other lands. Although they indicated that they see multiculturalism as a natural result of globalization and migration, most of the teacher candidates expressed their concern about people's readiness to it. They expressed that governmental institutions and civil society organizations must work together and create projects to solve this issue. Also, they viewed multiculturalism as the fastest remedy to heal traumas of immigration. These analysis of teacher candidates showed parallelism with related literature (Ateş \& Yavuz, 2017; Görgün, 2017).

Another finding of the study is related to the relation between migration and poverty. Antonio Torres' book The Land (2017) was used in the survey of this topic. Teacher candidates discussed how poverty forced people to immigrate based on the story of Nelo who is the main character in the book. On the other hand, they expressed that migration can be a way to 
overcome poverty, but there may be various social, psychological and financial problems which immigrants and their families have to face and poverty may still be a problem in the place they migrate. Teacher candidates' solution to this was social justice and fair distribution of world's resources.

Another finding of the study is related to the effects of migration on women. To this aim, the film Dancer in the Dark (VonTrier, 2000) was analyzed. Teacher candidates expressed that women immigrate for various reasons like family problems, poverty, sexual violence, wars, exploitation and violation of human rights which is consistent with related literature (Barın, 2015; Ünlütürk Ulaş \& Kalfa, 2009). Also, they viewed the relation between immigration from the point of gender inequality in the society. Another issue emphasized was how migration made people, especially women and children, defenseless against abuse. Teacher candidates frequently expressed how poverty and other issues make life extremely harsh for women during the process of migration. All these conclusions made an emphasis on the fact that bad decisions given in a male-dominant world put the heaviest burden on women.

It is a known fact that immigrant women experience financial, physical, emotional and sexual violence (Yalçın, 2015). It is obvious that these conditions negatively affect their emotional world. In the film analysis activity, teacher candidates drew emotions-time graphic line of Selma who is the main character in Dancer in the Dark (VonTrier, 2000) movie. Analysis of the graphics showed that the most dominant feelings in the movie were sorrow, fear, anger, confusion and disappointment which were the feeling a women would most likely feel during the process of immigration. It was also pointed that the only shelter Selma could find were music and rhythm.

Another finding of the study is related to teacher candidates' views of immigrant children and their education. Children are severely affected from migration as well as women. During the process of migration, children also experience very serious problems which are being deprived of education and good living conditions and being vulnerable to sexual abuse and unhealthy conditions (Özvarış, 2018). Teacher candidates expressed that after the session which included current data and real life stories, they better realized seriousness of the situation and deeply felt the reality as prospective teachers. 
Immigrant children have to work to contribute their families (Baş et al.,2017; Kaştan, 2015) and they are even forced to marriage (Türkay, 2016). Immigrant families neglect their children's educational needs as they have to deal with other problems caused by migration. This situation reveals how important it is to have migration sensitive educational systems and teachers. Teacher candidates summarized characteristics of migration sensitive educational systems with following words: It has to enable respect for diversity; it has to overcome various issues like compliance problems, peer conflicts and indifference of parents; it has to include sports and artistic activities; it has to be responsive to traumas caused by migration; it has to be equalitarian and multicultural; it has to provide schooling opportunities for immigrant children and help them effectively integrate with their schools.

Teacher candidates summarized characteristics of migration sensitive teachers with following words: They are sensitive to individual and cultural differences; they have a strong sense of empathy; they can think critically, they are respectful, peaceful, open minded, tolerant; their ethical values don't let them discriminate among people; they are open to global citizenship and multiculturalism; they are knowledgeable about children's rights, peace education, conflict resolution; they can actively use educational games, problem solution techniques, cooperative learning, creative drama and other teaching techniques; they are able to increase interaction between immigrant children and other children; they are aware of current event in their county and in the world; they are open to lifelong learning and educational innovations. These characteristics mentioned by teacher candidates are relevant to characteristics of multicultural teachers in related literature (Başbay \& Bektaş, 2009).

The findings related to conflict resolution activities showed that teacher candidates found this session very effective. In this session, teacher candidates first created possible conflict scenarios which may emerge in immigrant children's schools using all skills and knowledge they obtained in prior sessions and then they acted these scenarios and resolved conflicts. Analysis of teacher candidates' diaries showed that they believed every teacher should be experienced about conflict resolution and mediation (Türnüklü, Kaçmaz, İkiz \& Balc1,2009) and they should transfer these knowledge and skills to their students.

The findings of the last session of MEP which included six hat thinking activity showed that teacher candidates related: objective information about migration with white hat; all positive 
and negative emotions such as hope, happiness, trauma, stress, loneliness, disappointment with red hat; better health, education, financial and living standards with yellow hat; all problems related to migration such as othering, unemployment, security, housing, exploitation with black hat; all creative projects in arts, sports, economy, etc. with green hat; and the reality that migration is an undeniable phenomenon which carries both opportunities and risks and for this reason world has to urgently prepare itself and its institutions to this phenomenon with blue hat. As a matter of fact, Turkey receives a lot of internal and international migration and as a result of its geographical location it is a transit point for migration (İçduygu, Erder \& Gençkaya, 2014). It is known that this situation has major effects on social, economic, cultural and spatial structure of Turkey (Baş et al.,2017; Ekici \& Tuncel, 2015; Kaştan, 2015; Özvarış, 2018; Tümtaş \& Ergun, 2016). This finding of the study shows that teacher candidates can interpret various aspects of migration which are parallel to related literature.

Findings of group interviews can be grouped under three sections. Firstly, teacher candidates were asked "What do you think are the effects of MEP to teacher candidates participated in program?". All of the teacher candidates answered that they thought MEP was beneficial. The reason for importance of such an education was further explained by teacher candidates as: "Turkey is in the route of migration and currently hosts 4 million immigrants (GİGM, 2016), nearly half of these people are children but there aren't enough courses in education faculties about this issue". For this reason they emphasized that this kind of programs can be very beneficial for teachers.

The second question posed in group interviews was "What is the activity you most favored in MEP?'. Findings of the study show that content and activities used in MEP was found effective by teacher candidates. I was found that film analysis (F:30), creation and acting of conflict resolution scenarios, and six hat thinking activity were the most favored activities. Review of literature also shows that using films in educational activities has positive effects on deeper analysis of characters and topics; making topics easier to understand; generating solutions; and including more real life experiences (Yakar-İnce, 2013). Additionally, various studies support that creative drama (Namdar \& Çamadan, 2016), six hats thinking technique (Şahin \& Çakmak, 2016), conflict resolution (Lane-Garon, Ybarra-Merlo, Zajac \& Vierra, 2005) are effective methods in higher education. 
The last question posed to teacher candidates in the interviews was "What are your suggestions for improvement of MEP? " Teacher candidates' answers included following suggestions: Inviting specialists to sessions, visiting temporary education centers, and including more creative drama, film analysis and documentaries about migration.

In conclusion, Migration Education Program raised teacher candidates awareness of the phenomenon of migration; enabled them to describe characteristics of immigrant population in the world and Turkey, helped them to analyze various aspects of migration such as children, women poverty, globalization, multiculturalism; evaluate effects of migration on education; generate ideas related to migration sensitive education and teachers. In addition, the program was found effective by teacher candidates.

\section{Suggestions for Future Research}

1) Current study, which is about MEP, was designed using case study research method which is one of qualitative research methods. Further research can be designed using mixed methods by including various scales such as multiculturalism, global citizenship, democratic attitudes, etc. or written exams relevant to aims of education program.

2) The content of MEP can be further improved by including different films, documentaries, field trips, experts and other activities. By this way, the program can be suggested for implementation in education faculties and in-service training of teachers. 


\section{References}

Altınbaş, D. (2006). Avrupa ve çokkültürlülük: Fransa örneği. [Europe and multiculturalism: The case of France] Stratejik Analiz, 78, 52-61.

Apak, H. (2014). Suriyeli göçmenlerin kente uyumları: Mardin örneği. [Adaptation of the Syrian Immigrants to Urban: A Case Study of Mardin] Mukaddime, 5(2), 53-70.

Ateş, H., \& Yavuz, Ö. (2017). Immigrant othering and multiculturalism. Suleyman Demirel University The Journal of Faculty of Economicsand Administrative Sciences, 22, Special Issue on Migration, 1317-1327.

Aydın, D., Şahin, N., \& Akay, B. (2017). Göç olayının çocuk sağlı̆̆ı üzerine etkileri. [Effects of immigration on children's health] İzmir Dr. Behçet Uz Çocuk Hast. Dergisi, 7(1), $8-14$

Barın, H. (2015). Türkiye'deki Suriyeli kadınların toplumsal bağlamda yaşadıkları sorunlar ve çözüm önerileri. [Syrian women in Turkey: Social struggles and solution proposals] Göç Araştırmaları Dergisi, 1(2),10-56.

Barın,T. (2016). Farklılıkların bir arada yaşamasında liberal bir yaklaşım: Çok kültürlülük teorisi. [A liberal approach to living together: Multiculturalism theory Yıldırım Beyazıt Hukuk Dergisi, 2(1),57-88.

Baş, M., Molu, B. , Tuna, H., \& Baş, İ. (2017). Göç eden ailelerin sosyo-kültürel ve ekonomik değişiminin kadın ve çocuk yaşamına etkisi. [The Effects of The Socio-Cultural and Economic Change of Emigrant Families on The Lives of Women and Children] Insan ve Toplum Bilimleri Araştırmaları Dergisi, 6(3), 1680-1693.

Başbay, A. (2014). Çokkültürlü eğitim kapsamındaki derslerinin incelenmesi: Georgia state üniversitesi örneği. [Investigation of multicultural education courses: The case of Georgia state university Educational Sciences: Theory \& Practice,14(2),585-608.

Başbay, A., \& Bektaş, Y. (2009). Çokkültürlülük bağlamında öğretim ortamı ve öğretmen yeterlikleri. [Instructional environment and teacher competences in the context of multiculturalism] Education and Science, 34, 30-43. 
Başterzi, A.D. (2017). Mülteci, sığınmacı ve göçmen kadınların ruh sağlığı. [Mental Health of Refugee, Asylum Seeker and Immigrant Women] Psikiyatride Güncel Yaklaşımlar, 9(4) 379-387 .

BMMYK (BM MÜLTECİ ÖRGÜTÜ) (2015). Dünyada ve Türkiye'de Mülteciler [Refugees in the world and Turkey] Retrieved June 27, 2018, from https://www.tusev.org.tr/ usrfiles/files/Selen_Elif_Ay_Suriyeli_Multecilerin_Durumu.pdf

Canbay Tatar, H. (2013). Sürgünler mekanı dünya: göç, çokkültürlülük ve ötekileştirme. [World, the place of exiles: Migration, multiculturalism and othering] E-Journal of New World Sciences Academy, 8, (1), 72-81.

Çağlayan,S., \& Kemik, A.(2018). Kırdan kente iç göç süreciyle kadınların iş yaşamına katılımları ve sonuçları. [Participation and results of women in business life through internal immigration process from rural to urban] Süleyman Demirel Üniversitesi Fen Edebiyat Fakültesi Sosyal Bilimler Dergisi, 43,143-157.

Damgacı,F., \& Aydın, H. (2013). Akademisyelerin çokkültürlü eğitime ilişkin tutumları. [Attitudes of the academicians towards multicultural education] Elektronik Sosyal Bilimler Dergisi, 12(45), 325-341.

Demirdizen, D. (2013). Türkiye'de ev hizmetlerinde çalışan göçmen kadınlar [Domestic migrant women workers in Turkey] Çalışma ve Toplum, 3, 325 - 346.

Deniz, A.Ç. Hülür, A.B., \& Ekinci, Y. (2016). Göç, strateji ve taktik: Suriyeli sığınmacıların gündelik hayat deneyimleri. [Migration, strategy and tactic: Everyday life experiences of the syrian asylumseekers] Uluslararası Sosyal Araştırmalar Dergisi, 9 (42), 1077 1087.

Doğanay, H. (1994). Türkiye beşeri coğrafyası. [Human geography of Turkey] Gazi Büro Yayınevi: Ankara.

Ekici S., \& Tuncel, G. (2015). Göç ve insan. [Migration and human] Birey ve Toplum, 5(9), 9-22.

Gencer T.E. (2017). An evaluation of the relationship of immigration and education: Education needs of the Syrian refugee children and challenges of exposed delays in schooling processes The Journal of International Social Research, 10(54), 1-14.

Giddens, A., (2008). Sosyoloji [Sociology] (Hzl: C. Güzel), İstanbul: Kırmızı Yay. 
GİGM (2016). Türkiye göç raporu [Turkey migration report], Retrieved June 27, 2018, from http://www.goc.gov.tr/files/files/2016_yiik_goc_raporu_haziran.pdf

Gökmen, Ç.E. (2011). Türk turizminin yabancı gelinleri: Marmaris yöresinde turizm sektöründe çalışan göçmen kadınlar. [Foreign brides of Turkish tourism: Migrant women working in tourism sector in Marmaris region] Çalışma ve Toplum,1, 201-232.

Görgün, M. (2017). The importance of migrant social networks in the process of globalization Suleyman Demirel University The Journal of Faculty of Economicsand Administrative Sciences, 22, Special Issue on Migration, 1317-1327.

Gözübüyük, A.A., Duras, E,. Dağ, H., \& Arıca, V. (2015). Olağan üstü durumlarda çocuk sağlığı, [Child health in case of emergency] Journal of Clinical and Experimental Investigations, 3,324-330.

Hollifield, James F. (James Frank), 1954- \& Brettell, Caroline B., 1950- (2000). Migration theory : talking across disciplines. Routledge, New York; London.

IOM. (2012). Göçmen çocuk raporu, Türkiye'de göçmen çocukların profili, sosyal politika ve sosyal hizmet önerileri hızlı değerlendirme araştırması. [Immigrant children's profile in turkey and social services social policy recommendations for quick assessment survey] Retrieved June 27, 2018, from http://www.turkey.iom.int/tr

İçduygu, A. Erder S., \& Gençkaya,. Ö. F. (2014). Türkiye'nin uluslararası göç politikaları, 1923-2023 [International Migration Policies of Turkey, 1923-2023] MiReKoç Proje Raporlar1.

İskan Kanunu (2006). İskan Kanunu [Settlement Law]. Retrieved June 7, 2018, from http://www.mevzuat.gov.tr/MevzuatMetin/1.5.5543.pdf

Kağnıcı, D.Y. (2017). Suriyeli mülteci çocukların kültürel uyum sürecinde okul psikolojik danışmanlarına düşen rol ve sorumluluklar. School counselors' roles and responsibilities in cultural adaptation process of Syrian refugee children Elementary Education Online, 16(4), 1768-1776. 
Kaştan, Y. (2015). Türkiye'de göç yaşamış çocukların eğitim sürecinde karşılaşılan problemler. [Problems on migration process of children lived in Turkey] Uluslararast Sosyal ve Eğitim Bilimleri Dergisi, 2(4), 216-229.

Korkmaz, A., \& Korkut, G. (2012). Türkiye'de kadının işgücüne katılımının belirleyicileri. [The determinants of female participation to labour force in Turkey] Süleyman Demirel Üniversitesi İktisadi İdari Bilimler Fakültesi Dergisi, 17(2), 41-65.

Köşk, U., \& Özbek, Ç. (2017). Küreselleşme ve uluslararası göç ilişkisinde değişen göçmen alg1s1. [Changing perception of immigrants in the relation of globalization and international migration] Researcher: Social Science Studies, 5(8), 247-265.

Lane-Garon, P., Ybarra-Merlo, M., Zajac, J.D., \& Vierra, T. (2005). Mediators and mentors: Partners in conflict resolution and peace education. Journal of Peace Education, 2(2), 183-193.

Mertens, D. (1998). Research methods in education and psychology. London: Sage.

Namdar A. O., \& Çamadan F. (2016). The Effect of Creative Drama Practices on Pre-Service Teachers' Social Skills. GUJGEF, 36(3), 557-575.

Özvarış, Ş.B. (2018). Göç ve Kadın Sağlığı. [Migration and Women's Health] Retrieved May 17, 2018, from http://www.emo.org.tr/ekler/67f89c8238f038d_ek.pdf?dergi=1117

Pala, A. (2013). Zorunlu göç ve kadın deneyimi: Diyarbakır örneği. [Forced Migration and Women Experience: Example of Diyarbakır] Hacettepe Üniversitesi Sosyal Bilimler Enstitüsü. Antropoloji Anabilim Dalı Ankara.

Saraydın, G. (2007), Kadın Mülteciler, [Women Refugees] Uluslararası Göç ve Kadın Sempozyumu Bildiriler.01-02 Aralık 2007, Zeytinburnu Belediyesi Kültür Yayınları:12, 64-66, İstanbul.

Schröttner, B.T. (2012). The need for global consciousness: Debate on globalization, migration, and education. In D.A. Urias (Ed.). The Immigration \& Education Nexus.(P.21-36) Rotterdam:Sense Publishers.

Şahin, Ç., \& Çakmak, N. (2016). Evaluation of the worksheets based on six thinking hats and case study according to critical thinking skills: Heat and temperature, JOTCSC, 1(1), $31-62$. 
Şener, D.K., \& Ocakçı, A.F. (2014). Yoksulluğun Çocuk Sağlı̆̆ı Üzerine Çok Boyutlu Etkileri. [Multi-dimensional effects of poverty on children health] Ankara Sağllk Hizmetleri Dergisi, 13(1): 57-68.

Tores, A. (2017). Lanetli topraklar [The Land (Çev: Yasemin Yener), Bilgi Yayınevi, Ankara.

Tümtaş, M. S., \& Ergun C. (2016). The effects of migration on social and spatial structure. . Suleyman Demirel University The Journal of Faculty of Economics and Administrative Sciences, 21(4), 1347-1359.

Türkay, M. (2016). Çocukların sorunları, savaş, göç ve sağlık, [Problems of children, war, migration and health] Türk Tabipleri Birliği Yayınları: Ankara, 71-75.

Türnüklü, A., Kaçmaz, T., İkiz, E., \& Balcı, F. (2009). Anlaşmazlık çözümü, müzakere ve akran-arabuluculuk eğitim programı. [Conflict resolution, negotiation and peermediation training program] Maya Akademi, Ankara.

UNHRC (BM MÜLTECİ ÖRGÜTÜ) (2018). Retrieved June 27, 2018, from http://www.unhcr.org/tr/

UNICEF (2016). Köklerinden Koparılanlar: Mülteci ve Göçmen Çocukların Maruz Kaldığı Giderek Büyüyen Kriz Retrieved May 27, 2018, from http://www.unicef.org.tr/files/bilgimerkezi/doc/Uprooted-ES-Turkish.pdf

Ünlütürk Ulutaş, Ç., \& Kalfa, A. (2009). Göçün kadınlaşması ve göçmen kadınların örgütlenme deneyimleri. [The femininization of migration and migrant women's organization] Fe Dergi 1(2),13-28.

Von Trier, L. (Yön.). Karanlıkta Dans [Dancer in the Dark], Copenhagen: Zentropa, 2000.

Yakar-İnce, H.G. (2013). Sinema filmlerinin eğitim amaçlı kullanımı: Tarihsel bir değerlendirme. [The use of cinema films for education: A historical evaluation] Hasan Ali Yücel Ĕgitim Fakültesi Dergisi, 19(1), 21-36.

Yalçın, Ç. (2015). “Türkiye'de ev hizmetlerinde çalışan göçmen kadınlar ve ekonomik şiddet," [Immigrant women working in domestic services in Turkey and economic violence]. Fe Dergi, 7(1), 50-60.

Yalçın, C. (2004).Göç sosyolojisi. [Sociology of migration] Anı Yayıncılık, Ankara. 
Yalçın, C. (2002). Çokkültürcülük bağlamında Türkiye’den batı Avrupa ülkelerine göç. [Migration from Turkey to West European countries in the context of multiculturalism] Cumhuriyet Üniversitesi Sosyal Bilimler Dergisi, 26(1), 45-60.

Yıldırım A., \& Şimşek, H. (2008). Sosyal bilimlerde nitel araştırma yöntemleri, 7. Basım, [Qualitative research methods in the social sciences] Ankara: Seçkin Yayıncılık. 